\title{
TINJAUAN YURIDIS PERMASALAHAN DAN AKIBAT HUKUMNYA ATAS KEPUTUSAN MAJELIS PENGAWAS NOTARIS SEBAGAI OBJEK GUGATAN DI PENGADILAN TATA USAHA NEGARA
}

\author{
Andri Swasono*, Gunarto ** \\ Mahasiswa Program Magister (S2) Kenotariatan Fakultas Hukum UNISSULA, Semarang, e-mail: \\ wisata75@yahoo.co.id \\ ** Dosen Fakultas Hukum UNISSULA, Semarang, e-mail : gunarto@unissula.ac.id
}

\begin{abstract}
Research with a title "Juridical Review The Problems And The Legal Consequences Of The Decision Of Notary Supervisory Board As The Object Of Lawsuit In Administrative Court" examine the issues arising from the decision issued by the notary supervisory board whether it is a state administrative decision.

The decision of the notary supervisory board is an administrative decision which can be used as the object of lawsuit in state administrative court as referred to in the terms of the state administrative decision, namely a written stipulation issued by the agency / officials of state administration which contains administrative legal action based on laws and regulations, which is a concrete, individual, and final, and have a legal effect on a person or civil legal entity.

To be able to become the object of a lawsuit after first ensured it is not a state administrative decision which is exempted as meant in Article 2 and Article 49, and shall be ensured that all administrative efforts have been taken.
\end{abstract}

Keywords: notary supervisory board, state administrative decision, object of lawsuit.

\section{PENDAHULUAN}

Pengaturan tentang pengawasan terhadap Notaris mengalami beberapa perubahan setelah reformasi tahun 1998, Reglement op Het Notaris Ambt in Indonesia (Stb.1860:3) yang dahulu dijadikan pedoman untuk mengatur jabatan Notaris oleh Undang-Undang Republik Indonesia Nomor 30 Tahun 2004 tentang jabatan Notaris dinyatakan oleh Dewan Perwakilan Rakyat dan Presiden Republik Indonesia tidak sesuai lagi dengan perkembangan hukum dan kebutuhan masyarakat. Terbitnnya Undang-Undang Nomor 30 Tahun 2004 Tentang Jabatan Notaris itupun dirasa belum cukup, sehingga pada tahun 2014 terjadi lagi perubahan terhadap Undang-Undang tersebut lalu di Undangkanlah Undang-Undang Nomor 2 Tahun 2014 Tentang Perubahan Atas Undang-Undang Nomor 30 Tahun 2004 Tentang Jabatan Notaris yang kemudian lebih dikenal dengan UUJN (Undang-Undang Jabatan Notaris).

Banyak perubahan didalamnya, termasuk Tentang pengaturan pengawasan terhadap Notaris, sebelum berlakunya UUJN, pengawasan, pemeriksa- an dan penjatuhan sanksi terhadap Notaris dilakukan oleh Badan Peradilan yang ada pada waktu itu, sebagaimana pernah diatur dalam Pasal 140 reglement op de rechtlijke organisatie en het der justitie (Stbl. 1847 No.23), Pasal 96 reglement buitengewesten, Pasal 3 ordonantie buitengerechtelijke verrichtingen- Lembaran Negara 1946 Nomor 135, dan Pasal 50 PJN. ${ }^{1}$

Kemudian pengawasan terhadap Notaris dilakukan Peradilan umum dan Mahkamah Agung sebagaimana tersebut dalam Pasal 32 dan Pasal 54 Undang-Undang Nomor 13 Tahun 1965 Tentang Pengadilan Dalam Lingkungan Peradilan Umum dan Mahkamah Agung, kemudian dibuat pula Surat Edaran Mahkamah Agung Republik Indonesia Nomor 2 Tahun 1984 Tentang Tata Cara Pengawasan Terhadap Notaris, Keputusan bersama Ketua Mahkamah Agung dan Menteri Kehakiman Nomor KMA/006/SKB/VII/1987 Tentang Tata Cara Pengawasan, Penindakan dan Pembelaan Diri Notaris.

\footnotetext{
${ }^{1}$ Habib Adjie, Majelis Pengawas Notaris Sebagai Pejabat Tata Usaha Negara, Refika Aditama, Bandung, 2011, halaman 1
} 
Bahwa, dari uraian tersebut diatas pengawasan Notaris dilakukan oleh Badan Peradilan, hal ini terjadi karena pada waktu itu Mahkamah Agung hanya mengurusi urusan teknis yudisial sedangkan hal-hal yang terkait dengan non teknis yudisial masih diatur oleh Departemen Kehakiman, baru pada Tahun 2004 sebagaimana amanat Undang-Undang Nomor 8 Tahun 2004 Pasal 5 ayat (1) Pembinaan Teknis Peradilan, Organisasi, Administrasi dan Finansial Pengadilan dilakukan oleh Mahkamah Agung. Sehingga sejak pengalihan tersebut adalah tidak tepat apabila pengawasan Notaris dilakukan oleh Badan Peradilan mengingat Menteri Kehakiman tidak mempunyai kewenangan apapun tehadap Badan Peradilan.

Oleh karena itu sesuai dengan Undang-Undang Nomor 30 Tahun 2004 tentang Jabatan Notaris yang kemudian dirubah dengan Undang-Undang Nomor 2 Tahun 2014 Tentang perubahan atas UndangUndang tersebut segala tindakan Notaris pengawasannya dilakukan oleh Menteri, dalam hal ini adalah Menteri yang menyelenggarakan urusan pemerintahan dibidang hukum, namun dalam pelaksanaannya Menteri membentuk Majelis Pengawas Notaris.

Majelis Pengawas Notaris adalah sebagai satusatunya lembaga yang berwenang melakukan pengawasan, pemeriksaan dan menjatuhkan sanksi terhadap Notaris, dan tiap jenjang Majelis Pengawas (MPD, MPW dan MPP) mempunyai wewenang masing-masing. ${ }^{2}$

Mencermati hal tersebut atas besarnya kewenangan yang dimiliki oleh Majelis Pengawas Notaris, menjadi hal yang menarik untuk diteliti adalah terhadap Keputusan Majelis Pengawas Notaris dapatkah digugat serta dijadikan sebagai Objek Gugatan di Pengadilan Tata Usaha Negara.

\section{METODE PENELITIAN.}

Dalam penelitian ini menggunakan metode pendekatan diskriptif kualitatif yaitu, cara pendekatan terhadap masalah-masalah yang akan diteliti dengan didasarkan pada asas-asas hukum, kaedah-kaedah hukum, peraturan perUndang-Undangan yang berlaku dan teori-teori hukum yang berhubungan

2 Achmad Ali dan Wiwie Heryani, Asas-Asas Hukum Pembuktian Perdata, Kencana Prenada Media Group, Jakarta, 2012, Halaman 1 dengan permasalahan serta memberikan kerangka pembuktian atau kerangka pengujian untuk memastikan suatu kebenaran. Metode pendekatan Diskriptif kualitatif merupakan cara atau prosedur yang dipergunakan untuk memecahkan masalah penelitian, dengan meneliti data primer kemudian data sekunder terlebih dahulu dilanjutkan dengan mengadakan penelitian terhadap data di lapangan.

Pendekatan dilakukan juga dengan cara melakukan telaah terhadap kasus-kasus yang berkaitan dengan isu yang dihadapi yang telah menjadi Putusan Pengadilan yang telah mempunyai kekuatan hukum tetap. ${ }^{3}$

Penelitian hukum normatif seringkali juga diklasifikasikan sebagai penelitian kualitatif. Perbedaan antara penelitian kualitatif dan penelitian kuantitatif adalah pada sifat data, karena penelitian itu menyangkut data dan konsekuensinya pada analisisnya.

Sumber bahan hukum yang digunakan dalam penelitian ini meliputi bahan hukum primer, sekunder dan tersier. Bahan Hukum Primer yaitu meliputi: Undang-Undang Nomor 5 Tahun 1986 Tentang Peradilan Tata Usaha Negara, Undang-Undang Nomor 9 Tahun 2004 Tentang Perubahan Atas Undang-Undang Nomor 5 Tahun 1986 Tentang Peradilan Tata Usaha Negara, Undang-Undang Nomor 51 Tahun 2009 Tentang Perubahan kedua atas Undang-Undang Nomor 5 Tahun 1986 Tentang Peradilan Tata Usaha Negara, Undang-Undang Nomor 30 Tahun 2004 Tentang Jabatan Notaris, Undang-Undang Nomor 2 Tahun 2014 Tentang Perubahan Atas Undang_undang Nomor 30 Tahun 2004 Tentang Jabatan Notaris, Putusan Pengadilan.

Bahan Hukum Sekunder dalam penelitian ini berupa penelusuran bahan pustaka berupa bukubuku, disertasi, tesis-tesis, jurnal-jurnal ilmiah, maupun artikel-artikel ilmiah yang berkaitan serta terkait dengan Keputusan Tata Usaha Negara, Majelis Pengawas Notaris.

Bahan hukum tersier, meliputi kamus atau insiklopedi kepustakaan yang berkaitan dengan Notaris, Administrasi Negara, Tata Usaha Negara.

\footnotetext{
${ }^{3}$ Peter Mahmud Marzuki, Penelitian Hukum, Kharisma Putra Utama, Jakarta, 2016, halaman 134.

${ }^{4}$ Philipus M.Hadjon, Tatiek Sri Djatmiati, Argumentasi Hukum, Gadjah Mada University Press, Yogyakarta, 2005, halaman 2.
} 
Setelah mempelajari semua bahan hukum, tahap selanjutnya adalah menganalisis bahan hukum, dengan menggunakan metode diskirptif kualitatif mengenai Keputusan Majelis Pengawas Notaris, Keputusan Tata Usaha Negara kaitannya dengan Objek Gugatan di Pengadilan Tata Usaha Negara

\section{HASIL PENELITIAN DAN PEMBAHASAN.}

Sengketa Tata Usaha Negara sebagaimana disebut dalam Pasal 1 angka 10 Undang-Undang Nomor 51 Tahun 2009 Tentang Perubahan kedua atas Undang-Undang Nomor 5 Tahun 1986 Tentang Peradilan Tata Usaha Negara adalah sengketa yang timbul dalam bidang Tata Usaha Negara antara orang atau Badan hukum perdata dengan Badan atau Pejabat Tata Usaha Negara, baik di pusat maupun di daerah, sebagai akibat dikeluarkannya Keputusan Tata Usaha Negara, termasuk sengketa kepegawaian berdasarkan peraturan perUndangUndangan yang berlaku.

Dari ketentuan tersebut dapat disimpulkan sengketa Tata Usaha Negara adalah sengketa yang selalu timbul antara orang atau Badan hukum perdata dengan Badan atau Pejabat Tata Usaha Negara akibat dikeluarkannya Keputusan Tata Usaha Negara. Di mana Keputusan Tata Usaha Negara menurut Pasal 1 angka 9 Undang-Undang Nomor 51 Tahun 2009 Tentang Perubahan kedua atas UndangUndang Nomor 5 Tahun 1986 Tentang Peradilan Tata Usaha Negara pengertiannya adalah suatu penetapan tertulis yang dikeluarkan oleh Badan atau Pejabat Tata Usaha Negara yang berisi tindakan hukum Tata Usaha Negara yang berdasarkan peraturan perUndang-Undangan yang berlaku, yang bersifat konkret, individual, dan final, yang menimbulkan akibat hukum bagi seseorang atau Badan hukum perdata.

Selanjutnya dari paparan diatas terhadap Keputusan Majelis Pengawas Notaris dapatkah dinilai telah memenuhi kriteria sebagai Keputusan Tata Usaha Negara yang dapat dijadikan sebagai Objek Gugatan di pengadilan Tata Usaha Negara. Bahwa, dari ketentuan Pasal tersebut dapat disimpulkan suatu Keputusan dapat disebut sebagai Keputusan Tata Usaha Negara apabila memenuhi 6 (enam) unsur berupa:

1. Penetapan tertulis;
2. Dikeluarkan oleh Badan atau Pejabat Tata Usaha Negara;

3. Berisi tindakan hukum Tata Usaha Negara;

4. Berdasarkan peraturan perUndang-Undangan yang berlaku;

5. Bersifat konkret, individual, dan final;

6. Menimbulkan akibat hukum bagi seseorang atau Badan hukum perdata.

Dan bersifat imperatif kumulatif, artinya ke 6 (enam) unsur tersebut wajib terdapat dalam suatu Keputusan tersebut, jika salah satu unsur saja tidak terdapat dalam Keputusan atau tidak terpenuhi, maka Keputusan tersebut bukan merupakan Keputusan Tata Usaha Negara dan tidak dapat disebut sebagai Keputusan Tata Usaha Negara.

Unsur ke-1 Penetapan tertulis artinya, Keputusan tersebut harus merupakan penetapan yang dikeluarkan secara tertulis dan bukan lisan. Istilah penetapan tertulis terutama menunjuk kepada isi dan bukan kepada bentuk Keputusan yang dikeluarkan oleh Badan atau Pejabat Tata Usaha Negara. Diharuskan tertulis bukan dinilai dari bentuk formalnya melainkan untuk memudahkan dari segi pembuktiannya. Bentuk formal dari suatu penetapan tertulis yang dikeluarkan oleh Badan atau Pejabat Tata Usaha Negara tidak menjadi syarat mutlak agar penetapan tertulis tersebut dapat disebut atau termasuk Keputusan Tata Usaha Negara, penjelasan lebih lanjut menyebutkan, bahwa sebuah memo atau nota bisa disebut merupakan suatu Keputusan Badan atau Pejabat Tata Usaha Negara, apabila sudah jelas:

a. Badan atau Pejabat Tata Usaha Negara Mana yang mengeluarkannya;

b. Maksud serta mengenai hal apa isi dari memo atau nota itu;

c. Kepada siapa memo atau nota itu ditujukan dan apa yang ditetapkan di dalamnya. ${ }^{5}$

Unsur ke-2 dikeluarkan oleh Badan atau Pejabat Tata Usaha Negara, unsur ini menentukan bahwa "penetapan tertulis" harus dikeluarkan oleh Badan atau Pejabat Tata Usaha Negara. Didalam Pasal 1 angka 8 Undang-Undang Nomor 51 Tahun 2009 Tentang perubahan kedua atas Undang-Undang Nomor 5 Tahun 1986 Tentang Peradilan Tata Usaha Negara yang dimaksud dengan Badan atau Pejabat

\footnotetext{
${ }^{5}$ R. Wiyono, Hukum Acara Peradilan Tata Usaha Negara, Sinar Grafika, Jakarta, 2015, halaman 18-19.
} 
Tata Usaha Negara adalah Badan atau Pejabat yang melaksanakan urusan pemerintahan berdasarkan peraturan perUndang-Undangan yang berlaku. Dengan kata lain, Badan atau Pejabat Tata Usaha Negara adalah Badan atau pejabat yang berdasarkan peraturan perUndang-Undangan yang berlaku, mempunyai wewenang untuk melaksanakan urusan pemerintahan.

Sebagaimana telah diuraikan sebelumnya tindakan untuk melakukan pengawasan atas Notaris adalah merupakan kewenangan menteri dalam hal ini adalah Menteri Hukum dan Hak Asasi Manusia (Pasal 67 Undang-Undang Nomor 2 Tahun 2014 jo Pasal 1 angka 5, Pasal 2 ayat (1) dan (2) Peraturan Menteri Hukum dan Hak Asasi Manusia) yang kemudian tindakan pengawasan itu didelegasikan kepada Majelis Pengawas Notaris. Sehingga kewenangan Majelis Pengawas Notaris melakukan pengawasan adalah merupakan kewenangan yang diperoleh secara atribusi oleh menteri yang kemudian dilimpahkan kepada Majelis Pengawas Notaris dalam bentuk delegasi. Dan tindakan pengawasan terhadap Notaris adalah merupakan urusan yang sifatnya urusan pemerintahan bukan merupakan kegiatan yang sifatnya legislatif maupun yudikatif. Sehingga dengan demikian unsur ke-2 pun telah terpenuhi yaitu Majelis Pengawas Notaris merupakan Badan atau Pejabat Tata Usaha Negara.

Unsur ke-3 berisi tindakan hukum Tata Usaha Negara, dalam penjelasan Pasal 1 angka 3 UndangUndang Nomor 5 Tahun 1986 dijelaskan, yang dimaksud dengan tindakan hukum Tata Usaha Negara adalah perbuatan hukum Badan atau Pejabat Tata Usaha Negara yang bersumber pada ketentuan hukum Tata Usaha Negara yang dapat menimbulkan hak atau kewajiban pada orang lain.

Penetapan tertulis sendiri sebenarnya sudah merupakan bentuk dari Keputusan dari Badan atau Pejabat Tata Usaha Negara, dan Keputusan semacam itu selalu merupakan suatu tindakan hukum Tata Usaha Negara. Dan suatu tindakan hukum Tata Usaha Negara adalah suatu Keputusan yang menciptakan, atau menentukan mengikatnya atau menghapuskanya suatu hubungan hukum Tata Usaha Negara yang telah ada. Maka Keputusan Badan atau Pejabat Tata Usaha Negara itu harus merupakan suatu tindakan hukum, artinya di maksudkan untuk menimbulkan suatu akibat hukum
Tata Usaha Negara. Apabila suatu perbuatan Badan atau Jabatan Tata Usaha Negara itu bukan merupakan suatu tindakan hukum (artinya tidak dimaksudkan untuk menimbulkan suatu akibat hukum Tata Usaha Negara), maka sudah tentu tidak dapat digugat ke Pengadila Tata Usaha Negara.

Selanjutnya unsur ke-4 berdasarkan peraturan perUndang-Undangan yang berlaku. Dari rumusan kata berdasarkan yang dimaksud adalah bahwa dalam setiap pelaksanaan urusan pemerintahan yang dilakukan oleh para Badan atau Pejabat Tata Usaha Negara itu harus ada dasarnya dalam peraturan perUndang-Undangan yang berlaku, karena hanya peraturan perUndang-Undangan yang berlaku sajalah yang memberikan dasar keabsahan (dasar legalitas) urusan pemerintahan yang mereka laksanakan.

Dari kata berdasarkan peraturan perUndangUndangan yang berlaku dimaksudkan wewenang Badan atau Pejabat Tata Usaha Negara untuk melaksanakan suatu bidang urusan pemerintahan itu hanya berasal atau bersumber dari wewenang yang diberikan oleh suatu ketentuan dalam peraturan perUndang-Undangan yang berlaku. Hal mana merupakan salah satu perwujudan dari berlakunya Indonesia sebagai negara hukum.

Majelis Pengawas Notaris dalam hal melakukan pengawasan terhadap Notaris didasarkan pada ketentuan Pasal 67 Undang-Undang Nomor 2 Tahun 2014 Tentang Perubahan Atas Undang-Undang Nomor 30 Tahun 2004 Tentang Jabatan Notaris, dalam melaksanakan pengawasan Menteri membentuk Majelis Pengawas Notaris. Sedang arti pengawasan sendiri menurut Peraturan Menteri Hukum dan Hak Asasi Manusia Nomor 40 Tahun 2015 adalah kegiatan yang bersifat preventif dan kuratif termasuk kegiatan pembinaan yang dilakukan oleh Majelis Pengawas Notaris.

Dan kewenangan pengawasannya meliputi pengawasan atas perilaku Notaris yang diatur dengan Kode Etik Notaris dan pelaksanaan atas Jabatan Notaris. Dan terhadap hal apa saja yang wajib dilakukan oleh Notaris maupun hal-hal apa saja yang tidak boleh dilanggar oleh Notaris telah dibahas sebelumnya. Sehingga dengan demikian Keputusan yang diterbitkan atau dikeluarkan oleh Majelis Pengawas Notaris dapat dimaknai berdasarkan peraturan perUndang-Undangan yang berlaku. 
Unsur ke-5 bersifat konkret, individual, dan final. Artinya objek yang diputuskan dalam Keputusan Tata Usaha Negara tersebut tidak abstrak, tetapi berwujud, tertentu atau dapat ditentukan. Terhadap Keputusan yang diterbitkan oleh Mejelis Pengawas Notaris kesemuanya dalam bentuk konkret dan tidak abstrak.

Bersifat individual, artinya Keputusan Tata Usaha Negara itu tidak ditujukan kepada umum, tetapi tertentu baik alamat maupun hal yang dituju. Apabila yang dituju lebih dari seorang, tiap tiap nama orang yang terkena Keputusan tersebut harus disebutkan, sehingga Keputusan demikian itu lalu dapat disebut suatu kumpulan penetapan tertulis. Karena Keputusan kepada masing-masing nama yang tersebut dalam lampirannya sebenarnya dapat berdiri sendiri-sendiri. Jadi Sifat individual itu berarti secara langsung mengenai hal atau keadaan tertentu yang nyata ada.

Keputusan Tata Usaha Negara yang dikeluarkan itu harus bersifat final, artinya akibat hukum yang ditimbulkan serta dimaksudkan dengan mengeluarkan penetapan tertulis itu harus benar sudah merupakan akibat hukum yang definitif. Menurut nalar Badan atau Pejabat Tata Usaha Negara itu pada suatu saat hanya dapat menimbulkan suatu macam akibat hukum terentu. Jadi dengan mengeluarkan suatu Keputusan Tata Usaha Negara yang definitif itu hanya ditentukan posisi hukum dari satu subjek atau objek hukum. Hanya pada saat itulah dikatakan, bahwa suatu akibat hukum itu telah ditimbulkan oleh Keputusan Tata Usaha Negara yang bersangkutan secara final.

Final berarti telah menimbulkan akibat hukum yang definitif, yaitu terhadap Keputusan tersebut sudah tidak perlu memerlukan persetujuan instansi lain atau Badan atau Pejabat Tata Usaha Negara lain, apabila masih memerlukan persetujuan instansi maupun Badan atau Pejabat Tata Usaha Negara lain hal itu belum bisa dikualifikasikan telah final.

Namun adakalanya untuk menentukan suatu Keputusan tersebut telah memenuhi unsur final atau belum harus dilihat kembali kepada ketentuan dasar yang mengaturnya. Atas Keputusan Majelis Pengawas Wilayah sebagaimana di maksud dalam Pasal 73 ayat Undang-Undang Nomor 2 Tahun 2014 Tentang Perubahan Atas Undang-Undang Nomor 2 Tahun 2004 Tentang Jabatan Notaris. Terhadap penjatuhan sanksi kepada Notaris berupa peringatan lisan maupun tertulis adalah bersifat final.

Unsur ke-6 menimbulkan akibat hukum bagi seseorang atau Badan Hukum Perdata. Adalah menimbulkan akibat hukum Tata Usaha Negara, karena penetapan tertulis yang dikeluarkan oleh Badan atau Pejabat Tata Usaha Negara yang menimbulkan akibat hukum tersebut adalah berisi tindakan hukum Tata Usaha Negara. ${ }^{6}$

Menimbulkan akibat hukum berarti menimbulkan suatu perubahan dalam suasana hubungan hukum yang telah ada. Karena penetapan tertulis itu merupakan suatu tindakan hukum, maka sebagai tindakan hukum ia selalu dimaksudkan untuk menimbulkan suatu akibat hukum. Apabila ia tidak menimbulkan suatu akibat hukum, maka ia bukan suatu tindakan hukum dan karenanya juga bukan suatu penetapan tertulis.

Sebagai suatu tindakan hukum penetapan tertulis harus mampu menimbulkan suatu perubahan dalam hubungan-hubungan hukum yang telah ada, umpama melahirkan hubungan hukum baru, menghapuskan hubungan hukum yang telah ada, menetapkan suatu status dan sebagainya. ${ }^{7}$

Dari kewenangan yang didapatkan Majelis Pengawas Notaris dalam semua tingkatan setiap Keputusan yang diterbitkannya telah menimbulkan akibat hukum, kecuali ditentukan lain oleh aturan dasarnya berupa masih dapat diajukannya keberatan maupun upaya administrasi lainnya.

Sehingga dengan demikian dapatlah disimpulkan bahwa, Keputusan Majelis Pengawas Notaris adalah merupakan Keputusan Tata Usaha Negara karena telah memenuhi rumusan dari Pasal 1 angka 9 Undang-Undang Nomor 51 Tahun 2009 sebagai perubahan kedua atas Undang-Undang Nomor 5 Tahun 1986 Tentang Peradilan Tata Usaha Negara.

\section{KESIMPULAN}

Mengingat Keputusan Majelis Pengawas Notaris dapat dikualifikasikan sebagai Keputusan Tata Usaha Negara, dengan demikian dapat digugat di Pengadilan Tata Usaha Negara, mengingat Sengketa Tata Usaha Negara adalah sengketa yang timbul dalam

\footnotetext{
${ }^{6}$ Op.cit, halaman 29.

7 Indroharto, S.H., Buku I Usaha Memahami UndangUndang Tentang Peradilan Tata Usaha Negara, Pustaka sinar harapan, 2000, Jakarta, halaman 174-175.
} 
bidang tata usaha negara antara orang atau badan hukum perdata dengan badan atau pejabat tata usaha negara, baik di pusat maupun di daerah, sebagai akibat dikeluarkannya keputusan tata usaha negara, termasuk sengketa kepegawaian berdasarkan peraturan perundang-undangan yang berlaku.

\section{DAFTAR PUSTAKA}

Habib Adjie, Majelis Pengawas Notaris Sebagai Pejabat Tata Usaha Negara, Refika Aditama, Bandung, 2011;

Achmad Ali dan Wiwie Heryani, Asas-Asas Hukum Pembuktian Perdata, Kencana Prenada Media Group, Jakarta, 2012;
R. Wiyono, Hukum Acara Peradilan Tata Usaha Negara, Sinar Grafika, Jakarta, 2015;

Indroharto, S.H., Buku I Usaha Memahami UndangUndang Tentang Peradilan Tata Usaha Negara, Pustaka sinar harapan, 2000

\section{Undang-Undang.}

Undang-Undang Nomor 2 Tahun 2014 Tentang Perubahan Atas Undang-Undang Nomor 2 Tahun 2004 Tentang Jabatan Notaris.

Undang-Undang Nomor 51 Tahun 2009 Tentang Perubahan Kedua atas Undang-Undang Nomor 5 Tahun 1986 Tentang Peradilan Tata Usaha Negara. 